ADDIN, Volume 13, Number 2, August 2019

\title{
Islam Nusantara as Strategy \\ for Indonesian Nasionalism Inauguration
}

\author{
Badrun \\ UIN Sunan Kalijaga Yogyakarta, Indonesia \\ badrun@uin-suka.ac.id
}

\section{Abstract}

The discourse on Islam Nusantara has become quite popular discussion among Indonesian society in the last two to three years. Not only in the grassroots level, Islam Nusantara also becomes a study in several Islamic institutions in Indonesia. In fact, there are some Islamic universities that have opened Islam Nusantara study program. On the one hand, many groups welcomed the studies of Islam Nusantara after being proclaimed by Nabdliyyin in the $33^{\text {th }} \mathrm{NU}$ Congress in Jombang, 2015. But on the other hand, there are some groups who reject Islam Nusantara and considered it as heresy in Islam. Essentially, Islam Nusantara is not a new movement, not a new mazhab, not a new ideology, and certainly not a new religion. Islam Nusantara is Islam that exists in the nation and is not sourced from the nation. However, Islam Nusantara accepts and accommodates national cultures as long as it does not contradict the Islamic rules (sharia). It means, Islam Nusantara compromises the culture, appreciates the land where they live, but it does not eliminate tradition as long as it is still in harmony with Islamic sharia. This can become the foundation of our nationalism inauguration. In other words, Islam Nusantara does not only discuss about religious issues, but also about nationalism.

Keywords: Islam Nusantara, Nabdlatul Ulama, Nationalism, Nationality. 
Abstrak

ISLAM NUSANTARA SEBAGAI STRATEGI PENETAPAN NASIONALISME INDONESLA. Wacana tentang Islam Nusantara telah menjadi diskusi yang cukup populer di kalangan masyarakat Indonesia dalam dua hingga tiga tahun terakhir. Tidak hanya di tingkat akar rumput, Islam Nusantara juga menjadi studi di beberapa lembaga Islam di Indonesia. Bahkan, ada beberapa universitas Islam yang telah membuka program studi Islam Nusantara. Di satu sisi, banyak kelompok menyambut studi Islam Nusantara setelah diproklamirkan oleh Nabdliyyin di Kongres NU ke-33 di Jombang, 2015. Namun di sisi lain, ada beberapa kelompok yang menolak Islam Nusantara dan menganggapnya sebagai bid'ah dalam Islam. Intinya, Islam Nusantara bukanlah gerakan baru, bukan mazhab baru, bukan ideologi baru, dan tentu saja bukan agama baru. Islam Nusantara adalah Islam yang ada di negara dan tidak bersumber dari bangsa. Namun, Islam Nusantara menerima dan mengakomodasi budaya nasional selama tidak bertentangan dengan aturan Islam (syariah). Artinya, Islam Nusantara mengkompromikan budaya, menghargai tanah tempat mereka tinggal, tetapi itu tidak menghilangkan tradisi selama masih selaras dengan syariah Islam. Ini bisa menjadi dasar pelantikan nasionalisme kita. Dengan kata lain, Islam Nusantara tidak hanya membahas tentang masalah agama, tetapi juga tentang nasionalisme.

Kata Kunci: Islam Nusantara, Nahdlatul Ulama, Nasionalisme, Kebangsaan.

\section{A. Introduction}

Suppose that Imam Abu Abdillah Muhammad bin Idris asy-Syafi'i who is known as Imam Syafi'i (767-820 M) is still alive now, perhaps he will not be surprised if he heard the term of Islam Nusantara that now spread in Indonesian land which is supported by one group on one side, but opposed by another group on the other side. ${ }^{1}$ Long before the term of Islam Nusantara was heard

${ }^{1}$ The term of Islam Nusantara now is not just popular in Nahdlatul Ulama (NU) circles that made it as the grand theme in the $33^{\text {th }}$ NU Congress on 1-5 August 2015 in Jombang, East Java. But now Islam Nusantara term is also getting more popular in the grass root society and in academic world. This indicates by some Islamic colleges that made Islam Nusantara as new department/major, for instance, Postgraduate School UIN Sunan Kalijaga Yogyakarta opens Magister Program (S2) Interdisciplinary Islamic Studies 
and started to take groundwork in academic study as it is now, Imam Syafi'i who wrote the book of al-Umm, has confirmed Islam as a religion that is able to compromise situation and condition of the nation, including the problems of nationalism and nationality. In any part of the world where Islam is exist, in the "Nusantara" that is the sky upheld by Imam Syafi'i. That is, the application of Islam adapted to the situation and conditions of the local nation.

It would be strange if contemporary Muslims were questioning-by not saying deliberately misleading - the term of Islam Nusantara now becomes important part of Islamic study in Indonesia. The reason is, in the era as-salaf ash-shalib Ulama, Islam Nusantara has been applied with different term or etymology, but it contains with same terminology. In other words, Islam Nusantara terminology actually is not new thing that emerged from Nahdlatul Ulama (NU) because the Ulama of as-salaf ash-shalih actually has applied Islam Nusantara paradigm in diversity, written in their writings.

One of the examples seen is when Imam Syafi'i adjusted Maghrib prayer time with Baghdad (Iraq) "national condition" and Egypt "national condition". When in Baghdad, in his qaul qadim, Imam Syafi'i said that Maghrib prayer time was started since sun set until the disappearance of the horizon (dusk) red. Hence, when Imam Syafi'i was in Egypt, said in his qaul jadid, Maghrib prayer time was only briefly, that was, from the time the sun set and ended when the Maghrib prayer was finished.

The difference in opinion of Imam Shafi'i while in Baghdad and Egypt, in the matter of determining the time of the Maghrib prayer, was not indicate his inconsistency in formulating figh, but

which one of the major is Islam Nusantara. Not just that, Nahdlatul Ulama Islam Religion College (STAINU) Jakarta also opens the same major. Some of other college in Indonesia also emphasizes on Islam Nusantara in the study forums so that Islam Nusantara became a very famous discourse. Moreover, several books that discuss Islam Nusantara are also issued so that getting more crowded the discourse on Islam Nusantara. See Ahmad Baso, Islam Nusantara: Ijtihad Jenius dan Ijma' Ulama Indonesia (Jakarta: Pustaka Afid, 2015). Also see, Munawir Aziz (ed.), Islam Nusantara: dari Ushul Figh hingga Paham Kebangsaan (Bandung: Mizan, 2015). 
rather, he tried adjusting his ijtihad with local national condition. The reason, when the sun set between Baghdad and Egypt showed a quite prominent difference. ${ }^{2}$

In the book of ar-Risalah_- the first book discussed ushul fiqh — written by Imam Syafi'i, clearly illustrated the methodology of Imam Syafi'i in finding, compiling and changing Islamic laws systematically, and adjusting legal changes to the development of the situation, conditions, and culture in each place. This case shows that practice of Islam cannot be separated from its national condition, such as (author's term) Indonesian nation, American nation, Brazilian nation, Australian nation, Egyptian nation, French nation, the Saudi Arabian nation, and so forth.

It is very unlikely that the practice of Islam in Saudi Arabia, for instance, is equalized with the practice of Islam in Indonesia nation. Surely there are several characteristics and differences that cannot be matched, but still refer to the same principals and foundation, that is, Qur'an and Sunnah.

Normative and historical approach can be used as philosophical foundation and theoretical framework to expose and undertake critical reading or theoretical framework toward Islam Nusantara, especially as nationalism foothold in Indonesian context. In a general Indonesian dictionary, W.J.S. Poerwadaminta said that history is an occurrence and events that actually happened in the past or important events that really happened. The definition emphasizes on the events without linked to the other aspects. Whereas in comprehensive definition about a historical event, it also needs to see who undertakes the event, when, where, and why

${ }^{2}$ Actually not just in determination of Maghrib prayer time that showing Imam Syafi'i emphasizes on Islam Nusantara. In other issues, Imam Syafi'i also accommodates local cultures in his figh formulation. For instance, in the aqil baligh requirement person who permuted to marry and become witness, requirement become Salat Imam, requirement become the children custody, legal trading requirements, and so forth. See Ahmad Nahrawi Abdus Salam al-Indunisi, Ensiklopedia Imam Syafi'i: Biografi dan Mą̧bab Fiqh Terbesar Sepanjang Masa (Jakarta: Penerbit Himah, 2008), 207. 
the event occurs. ${ }^{3}$ While the word normative comes from English norm, which means the norms of teaching, references, provisions about good and bad problems that can be done and which cannot be done. ${ }^{4}$

In the context of discussion about Islam Nusantara, the side of historicity is the form of history of how the actual Islam Nusantara emerged and how it is interpreted in the current period. ${ }^{5}$ While the normativity side is the standard rules that exist in the teachings of Islam both sourced from Qur'an, Hadith, Ijma' of the ulama, Qiyas, and the norms that are recognized as validity in Islamic civilization, which becomes the basic practice of Islam Nusantara. Normativity cannot be detached from Islam Nusantara because Islam Nusantara is a teaching that cannot be separated from the teachings carried by Rasulullah.

Normativity and historical approach, in the study of Islam Nusantara ala NU (an-nabdliyyah) as nationalism foothold in Indonesian context, not only bring descriptive interpretation about the comprehensive teachings of Islam Nusantara and contribution of NU in Nationalism inauguration but it will also illustrate the extent to which the urgency and significance of Islam Nusantara teachings developed by NU based on previous ulama's thoughts, especially for the life of the Indonesian people today.

With both approaches, it will be concluded that if Islam Nusantara ala NU (an-nabdliyyah) is really closed to Islam and social (shariah and social inference) that can be used as foothold in Indonesian nationalism inauguration context or the opposite. ${ }^{6}$

${ }^{3}$ W.J.S. Poerwadaminta, Kamus Umum Bahasa Indonesia (Jakarta: National Language Institute, 1972), 284.

${ }^{4}$ Poerwadaminta, 301.

${ }^{5}$ In this case, Islam Nusantara actually is not a new teaching. So that, Islam Nusantara is a teaching that actually also practiced by Rasulullah in the different term but contain the same substance.

${ }^{6}$ Concept approach in studying every issue in Islam with this form had been proposed by Louay Safi in his book which later became reference for many Muslim intellectuals around the world until now. See, Louay Safi, The Foundation of Knowledge: a Comparative Studying Islamic and Western Methods of Inquiry (Selangor: IIU and IIIT, 1996), 171-196. 
Simply, the approach tries to connect normativity of the Divine text with the historicity of empirical reality related to Islam Nusantara, by simultaneously combining textual approach (normative) and contextual approach (historical-empirical).

Through normativity and history, as philosophical foundation or theoretical framework to study Islam Nusantara ala NU (annabdliyyab), it will emerge opinion about Islam Nusanatara from ideal paradigm that is empirical and worldwide. In this case, doctrine developed by Islam Nusantara needs to be clashed with factual present context.

For instance, many people call Islam Nusantara as a deviate sect. This surely needs to be clashed with practical concept of Islam and figh formulation conducted by classical ulama related to the local national condition. With this, the paper will give description and concrete conclusion whether Islam Nusantara indeed deviate or not, according to Islamic teachings, or the opposite. Thus, this paper will provide an overview of the teachings that actually relate to Islam Nusantara. From here, someone will not understand Islam Nusantara out of its historical context because the understanding will mislead people who understand it.

With theoretical framework explained above in order to discuss Islam Nusantara's issue, there are several main points emphasized in this paper. First, idealism approach, that is an effort to understand and interpret facts about Islam Nusantara both normatively and historically without any doubts whatsoever. Second, diachronic, is an effort to search for history of Islam Nusantara started before the emerging term of Islam Nusantara in Indonesia or after, thus will arise description about the truth or any mistakes behind Islam Nusantara teachings. Third, synchronic, is an effort to contextualize Islamic values both sociologically, culturally, and politically about the practice of Islamic teachings that now applied by many countries in the world, including Indonesia. This is intended to bring up 
description whether teaching of Islam Nusantara is wright or just the opposite.

\section{B. Discussion}

\section{An-Nahdliyyah Terminology of Islam Nusantara}

Before this scientific paper discusses further about Islam Nusantara ala NU (an-nabdliyyah) as nationalism foothold, the writer needs to stress on the definition about Islam Nusantara an-nabdliyyah or Islam Nusantara ala NU. So far, there are not many writings define Islam Nusantara comprehensively either in freelance article writings or scientific writings. The absence of the comprehensive definition causes some groups to be allergic toward Islam Nusantara. In fact, undivided, there are some parties state that Islam Nusantara is deviate and misleading. ${ }^{7}$

There many things need to be explained in the definition of Islam Nusantara, in order to avoid misunderstanding among society and also give understanding that Islam Nusantara ala NU (an-nabdliyyah) can be the basis to strengthen our nationalism. First, Islam Nusantara is not a new teaching, nor a new madhhab, a new ideology, and of course it is not a new religion. Second, Islam Nusantara is not only a concept talks about the matter of ritual worship, but also, it discusses other aspects such as government, culture, including also nationalism.

Third, Islam Nusantara is Islam in nation and does not sourced from nation. Fourth, Islam Nusantara accepts and accommodates the cultures of the nations as long as it does not contradict with Qur'an and Prophet's hadith. Fifth, Islam Nusantara renders national culture as the main part inseparable with Islamic practice, as long as its national culture does not contradict with Qur'an and Prophet's

\footnotetext{
${ }^{7}$ Many figures openly reject Islam Nusantara even stating strictly that Islam Nusantara is deviate Islam. Among many figures who reject Islam Nusantara in the da'wah of Islam is Mamah Dedeh and some other figures. Source: http://www.dakwatuna. com/2015/07/16/71768/soal-islam-nusantara-penolakan-mamah-dedeh-dan-kritikuntuk-wasekjen-pbnu/\#axzz4HaqZ0txi, accessed on August 8, 2016.
} 
hadith. Sixth, Islam Nusantara is Islam (can) eliminate Arabic culture (the Arabic things) then change it to national culture, in terms of Arabic culture (the Arabic things) is not including principle and basic requirement of the worship activity.

Above the all sixth definitions on Islam Nusantara, it is surely still needed example and further explanation. For instance, Islam Nusantara as what developed by NU is always in harmony and line with nationalism and national spirit. Because, Islam Nusantara always upholds "political agreement" occurs in a country (read: nation), in this case is Indonesia. In other words, Islam Nusantara always supports and maintains government system that has been prevailed in Indonesia, upholds the concept of Unitary State of Republic of Indonesia (Negara Kesatuan Republik Indonesia, NKRI), and maintains democracy values, as long as it does not contradict universal Islamic values. This case is accordance with NU viewpoint that NKRI is final, for the majority of the Indonesian Muslims. It also means that the form of an Islamic state is not desired by the majority of Indonesian Muslims. This was also emphasized again in the Nahdlatul Ulama Information to support Pancasila, the Constitution 1945, and Unitary State of Republic of Indonesia (NKRI). ${ }^{8}$

Besides that, the concept of Islam Nusantara, developed by $\mathrm{NU}$, said as the religion that (can) eliminate Arabic culture (the Arabic things) and replace it to national culture, as long as the Arabic culture (the Arabic things) is not included in requirement and principle of a worship activity. It means, there are several Arabic cultures or Arabic things that have already become absolute requirement and cannot be eliminated or replaced with other cultures in a ritual of Islamic religion. For instance, shalat must use Arabic language and cannot be replaced with national language (Indonesian language). So does with prayers call (azan) in every praying time, is also cannot be replaced with national language. However, in other ritual worship, there are

${ }^{8}$ Zudi Setiawan, Nasionalisme NU (Semarang: Aneka Ilmu, 2007), 250. 
some Arabic cultures that can be eliminated and be replaced with national culture. For example, marriage covenant read in Arabic language can be replaced with Indonesian language, Friday preach using Arabic language can be replaced with Indonesian language. Those things can be done because Arabic cultures in those rituals are not the requirement and principle.?

Those matters are consistent with the statement of PBNU Chairman, Said Aqil Siraj, who stated that Islam Nusantara does not lead to hate, burn, or kill. It is a teaching that compromises with the culture, realizes the land where he stands, and not eliminate tradition, as long as it is still in harmony with Islamic requirement. ${ }^{10}$

Therefore, Islam Nusantara is not a new understanding because the substance of the teachings of Islam Nusantara is in accordance with what has been applied by most Muslims in Indonesian and the world. Teachings of Islam Nusantara do not replace everything in Islam, that arised in Arab, with Indonesian cultures. Islam Nusantara also does not accept if all Indonesian culture becomes the main part of Islamic ritual practice. Because Islam Nusantara also acknowledges that there are some Arabic nuance in Islam cannot be erased or replaced with any other cultures, including Indonesian national culture.

However, what should be noted is that, as long as a culture is not against with Qur'an and Sunnah-although there never was the culture in the Prophet's era-then Islam Nusantara accommodates the culture as part of Islam and part of rituals practice in Islam. For example, the concept of democracy country which emphasizes on the highest protection and appreciation toward diversity as occur in Indonesia, the tradition of Prophet's birthday celebration, Tablilan, commemoration of Nuzulul Qur'an, birth thanksgiving, and any

${ }^{9}$ Betty Mauli Rosa Bustam, dkk, Sejarah Sastra Arab dari Beragam Perspektif (Yogyakarta: Deepublish, 2015), 86. See also Abdurrohman al-Baghdadi and Adian Husaini, Hermeneutika dan Tafsir Al-Qur'an (Jakarta: Gema Insani, 2007), 105.

${ }^{10}$ Jawa Pos, paper edition of July 27, 2015. 
other things. All of those can be used as inseparable part of Islamic religious rituals and can be preserved as cultural wealth of nation. ${ }^{11}$

Therefore, the practice of Islam Nusantara actually is an embodiment of Islam rabmatan lil 'alamin. ${ }^{12}$ In other words, for Islam can be said as religion with rahmatan lil 'alamin, Islam must be able to be applied in everywhere and condition (time and location) without any force and collision that can cause conflict. If Islam is only applied in Arab and needs coercion when applied in other countries, which is different with Arabic culture, so Islam cannot be said as religion with rahmatan lil 'alamin. From this, it can be understood that Islam Nusantara is actually as the essence of the real Islam.

\section{Islam Nusantara ala NU and Culture Compromise}

Through the explanation about Islam Nusantara in comprehensive definition above, it can be considered that Islam Nusantara which developed by NU actually presents a new hope on the strong religious pattern that is polite, peace, flexible, and compassionate to human beings, in any religions. Not a cruel-faced religion, full of hatred, spelling bloodshed in the name of holy God. This means that, it is because Islam Nusantara presents Islam that can be practiced in any groups of society, and in the middle of any cultural development. Besides that, in Indonesia context, Islam Nusantara ala NU also strengthens nationalism. Because Islam

\footnotetext{
${ }^{11}$ In its practice, the archipelago traditions such as Prophet birthday celebration, Tablilan, Nuzulul Qur'an commemoration, birth thanksgiving, and so forth, are accommodate is Islam and practiced with Islamic interlude. For example: celebrating prophet birthday by recite Shalawat al-Barzanji, celebrate birth safety by reacite Qur'an, shalawat whilst giving desert, and so on. These tradition has been done hereditary on the contrary can become da'wah media. See, Muhammad Sholikhin, Ritual dan Tradisi Islam Jawa: Ritual-ritual dan Tradisi-tradisi Tentang Kebamilan, Kelabiran, Pernikaban, Kematian dalam Kehidupan Sehari-hari Masyarakat Islam Jawa (Yogyakarta: Narasi Press, 2010), 133.

${ }^{12}$ Islam is rabmatan lil 'alamin religion which means Islam is a religion that brings grace and welfare to all universe, including animals, plants, and jins, especially fellow human. According to Allah words in Q.S. al-Anbiya [21]: 107 that says, "And, We have not sent you, except as a mercy to the world". See, Muhamad Guntur Romli, Islam Tanpa Diskriminasi: Mewrijudkan Islam Rabmatan lil 'Alamin (Jakarta: Rehal Pustaka, 2013), 23.
} 
Nusantara acknowledges the existence of a nation with political system applied before.

The question is, where is the significance and urgency of Islam Nusantara for Indonesian civilization particularly and world civilization generally? To answer the question, for a moment the writer wants to narrate dialogue between the writer and Irsyad Manji, a Muslim intellectual from Canada. The writer once was asked directly by Irsyad Manji in a book review entitled Allah, Liberty, and Love: the Courage to Reconcile Faith and Freedom (2011) in LKiS, Surowajan, Banguntapan, Bantul, Yogyakarta, 2012.

He asked, "Why the Indonesian architecture of the mosques mostly have similar architecture with mosques in Arabic countries and do not reflect architecture of Indonesian culture at all, such as Java, Bali, Sunda, or Madura? Do not always compel everything to be the same with Arab because it can make violence. Terrorism is one of them."

The writer cannot answer Irsyad Manjis question because indeed in many ways we always imitate Arab. If there is one Islamic ritual tries to eliminate Arabic symbols and at the same time appeals Indonesian symbols (non-Arab), this thing is regarded as violating the standard. In fact, it can be considered as a sin. In this case, the space for implementing Islam Nusantara is indeed very narrow. Many people do not agree if Islamic practice is mixed with culture “outside Islam".

Example of cases that has caused horrendous in Muslims in Indonesia is when the verses recitation of Qur'an in Isra' Mi'raj at State Palace, Jakarta, by a qari named Muhammad Yaser Arafat, using Javanese tune three years ago. The event provokes rage of many parties. For example, The Deputy Secretariat of Indonesian Ulama Council (Majelis Ulama Indonesia, MUI), Tengku Zulkarnaen, stated that Qur'an recitation with Javanese tune is ridiculous. According to him, this is considered to embarrass Indonesia in the eyes of the international community. 
For those who decline Qur'an recitation using Javanese tune, believe that the holy book of God must be recited using Arabic tune, Arabic intonation, and Arabic dialectic. Outside that, Qur'an recitation is considered incorrect. Is that right? Or, is there still a gap in Islamic hospitality for non-Arabs?

They, who decline Qur'an recitation using Javanese tune as a representation of Islam Nusantara practice, actually can be said as too exclusive and too imposing. Islam Nusantara is considered out of Islamic main requirement so that, not a few who consider it misguided and misleading. Even though, as mentioned in the beginning, the practice of Islam Nusantara-one of the example is recite Qur'an using Javanese tune-still stands on Qur'an and hadith, also scientific theory and methodology that can be accounted for.

In the case of Qur'an recitation using Javanese tune, we need to read the book The Phonology of Tone and Intonation (2004) by Carlos Gussenhoven. In this book, Carlos stated that someone's speech tune and intonation when speaking and reading, is impossible to change. It shaped by the environment since born and also tune recitation is impossible to be the same or likened. This is because their tongue was born and shaped by different environment and cultures. ${ }^{13}$

Therefore, any kind of Qur'an recitation tunes by Arabic person will never be the same with American, France, England, Italian, or Javanese tunes. From here, it is clear that to standardize Qur'an recitation tune is too imposing and useless effort. Furthermore, the effort will strengthen the opinion of some parties that Islam is an exclusive and anti-tolerance religion.

When we explore the norms of Islamic law, this religion has actually responded to cultural diversity with the birth of a fiqh rule which reads:

\footnotetext{
${ }^{13}$ Carlos Gussenhoven, The Phonology of Tone and Intonation (Cambridge: Cambridge University Press, 2004), 54.
} 


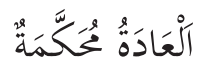

"Customs can be established as law."14

The theorem that was also acknowledged by Imam Syafi'i concluded that custom-including recites Qur'an using Javanese tune-can be used as a law or accepted as the truth within law, as long as it does not violate the main requirement of the Islamic rules. The theorem above is based on the Prophet's hadith that stated:

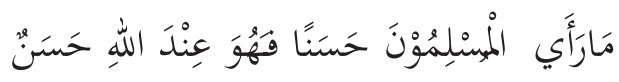

"What is considered good by the Muslims, then even in the sight of Allah.” (H.R. Bukhari) ${ }^{15}$

On that basic, Islam Nusantara that is guided by the customs applied in Islamic societies and does not violate the provisions of the shariah, can be determined as source of prevailed law and regarded as main part of Islamic practice. Whereas the custom that deviates from provisions of shariah, even though it is conducted by many people in the society, it cannot regarded as source of law.

This is where the need to implement Islam Nusantara in various context of religious rituals. So, does reciting Qur'an with Javanese tune violate Ulumul Qur'an or the basic requirements in reciting Qur'an? If so, then what are the binding provisions in reciting Qur'an that should not be violated and replaced with something else?

In the context of reciting Qur'an, for instance, the main provision in reciting Qur'an is its Tajwid or generally known as science/knowledge on principles and also how to recite Qur'an as good as possible. Reciting Qur'an can be wrong if it violates the provision of Tajwid rules. However, if we noticed from all the

\footnotetext{
${ }^{14}$ Muhammad Bagir, Figh Praktis (Bandung: Karisma, 2008), 67.

${ }^{15}$ Al-Bukhari, Shabih al-Bukhari, "Janaiz Book", hadith number of 1.296. Hadith Program.
} 
existing Tajwid provisions, there is no prohibition on reading Qur'an with Javanese, Sundanese, Sumatran, or Maduranese.

This Tajwid provision is actually still open for controversy. Because Tajwid and other accessories in Qur'an, (not the holy Qur'an) are a cultural product. In $62 \mathrm{H}$, Abul Aswad ad-Duali and Hajjaj bin Yusuf ats-Tsaqafi created dots in Arabic letters. In $180 \mathrm{H}$, Imam Khalil bin Ahmad al-Faraidi created Arabic reading signs in Qur'an such as fathah, kasrah, sukun, dammah, and etc. And, in around 210 H, Imam Abu Ubaid Qasim bin Salam (died in 224 H) created Tajwid science. Therefore, Tajwid is a cultural product and human creativity product, not purely the main provision in the revelation. ${ }^{16}$

Therefore, Islam Nusantara practice, as in the case of reciting Qur'an using Javanese tune, is actually not against the main provision of religion, in fact it is still in accordance with religion. This is one example of urgency and significance in Islam Nusantara toward Indonesia and the world civilization. Cultures that exist in our neighborhood-whatever its cultural type-become inseparable part from religious practice as long as the cultures are not against the main principle in religious teaching. Culture will be in line with religion, so that, religion is not far bounce with people live.

Therefore, one of the ways to get religion out of the ancient view by affirming a religion that is friendly to local wisdom, that is affirmed Islam Nusantara. Remember, radicalism understanding, that creates extreme action such as terrorism, starts with ancient view that forces everything must be exactly the same with what existed in Arab.

Not only in matters of ritual worship, the coercion is also proposed in government managing level, political system, law, leadership, dressing, business management, and etc. It means, Arab is qibla that is believed as the main and important part in religion.

\footnotetext{
${ }^{16}$ Muhammad Mustafa al-A'zami, Sejarah Tekes Al-Qur'an: dari Wabyu sampai Kompilasi (Jakarta: Gema Insani Press, 2005), 324.
} 
This ancient way of thinking must end immediately to look at the brighter future of religion.

In the Indonesian context, the form of emphasis on local wisdom in religion is to present a distinctive Islam Nusantara. Refer to the concept al-maqashid asy-syariah (the purposes of law enactment), all the local culture in Indonesia can be received in Islam, as long as it does not against hifž $h$ ad-din (preserve religion),

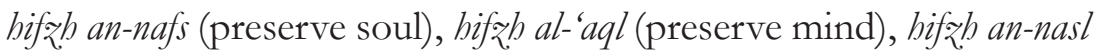
(preserve generation), and hifž al-mal (maintaining treasure). ${ }^{17}$

According to the writer, only by emphasizing on the local wisdom, Islam will be known as polite and peaceful religion, and religion that is worth to be applied in every time and location. Many wise persons state that, let us bring Islam to Indonesia, but do not bring Arab to Indonesia. Didn't the Walisongo succeed in spreading Islam for the first time in Java because they adopted local wisdom?

\section{Islam Nusantara ala NU (an-Nahdliyyah): Nationalism Stance}

In the discourse about the urgency of Islam Nusantara developed by NU, there is no harm if we take a look into Michael Barnes SJ in his book entitled Theology and the Dialogue of Religions (2002). Michael Barnes stated that "in the rising of conflict and friction because of faith disagreement in religion is directly proportional to the dialogue crisis among religions, between religion and culture, between religion and politics, also dialogue between religion and economy". ${ }^{18}$ It means, the further separated among religion and culture, economy, politic, even other religions, so then, the more friction and conflict will be opened. The conflicts can be in the form of radicalism in the name of religion, claiming the truth

${ }^{17}$ Yudian Wahyudi, Usbul Figh versus Hermeneutika: Membaca Islam dari Kanada dan Amerika (Yogyakarta: Pesantren Nawasea Press, 2007), 33.

${ }^{18}$ Michael Barnes SJ, Theology and the Dialogue of Religions (Cambridge University Press, 2002), 164. 
among religions or among one and other madhhab, rejection toward government system, nationalism crisis in the society, and so forth.

Not only that, Barnes adds, "religious teaching practice always opposes (against) culture and characteristic of culture that is attached hereditary, sooner or later it will cause conflict and bloodshed." 19

In other words, religion practice that in accordance with culture, political system, state management concept, actually can be a solution to muffle conflict among society. This case can be done by encouraging Islam Nusantara practice that emphasizes on dialogue about differences, compromises the culture, harmonizes with political system that already become common agreement, as well as emphasizes on the importance of concordance among humans. From this point, it will arise the high nationalism stance. And it is noticed or not, the practice of a religious teaching is also assisted in creating conflict between religions if it is always exclusive in the practice.

The Michael Barnes SJ thesis is what is currently happening. Almost every time we hear forms of religious radicalism occurs in Indonesia and in overseas that often result victims. For example: the existence of ISIS (Islamic State of Iraq and Syria) that often undertakes brutal action in various countries, includes in Indonesia. The writer will only mention two examples: First, brutal action in France, on November 2015. Second, is bomb in Thamrin Street, Jakarta, on January 2016. The both incidents were claimed by ISIS as their action and almost every parties were admitted that both incidents were ISIS action in which its headquarter is Iraq, however they have some members in other countries, such as in Indonesia. It means, now Indonesia is actually on the threatened condition toward nationalism.

The question is, why does it emerge anti-nationalism movements that threatened the existence of NKRI? There are

\footnotetext{
${ }^{19}$ Barnes SJ, 167.
} 
two possible answers presented. First, the movements of antinationalism - whatever its looks and forms-believe that movement and terror threatened the unity of NKRI with all of its movements, include taking casualties, are considered as jihad fi sabilillah (jihad in the name of Allah). Because, they believe that NKRI based on the Constitution 1945 and philosophy of Pancasila regarded as thaghut (villain) concept and it is not appropriate with Islamic teachings, so, it obliged to be fought. Second, the people who are killed by them are considered as kafir (non-muslim) that must be fought.

The evidence they used is Q.S. al-Fath [48]: 29, says:

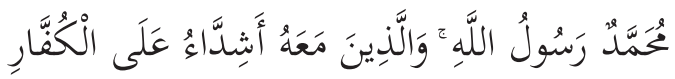

"Muhammad is the messenger of Allah, and those with him are forceful against the disbelievers." (Q.S. al-Fath [48]: 29)

The anti-nationalism movements such as ISIS (only mention one of them) make the above verse as a foothold and legitimacy to combat non-Muslims who are considered infidels, including all groups that obstruct their "struggle". This kind of Islamic understanding is clearly against Islamic teaching which essentially spreads compassion and peace to others. This kind of understanding emerges because Islam is separated from culture and brotherhood (ukhuwah) among humans in the nation. ${ }^{20}$

Unlike the case with the teachings of Islam Nusantara as developed by NU (Islam Nusantara an-Nabdliyyab) exactly emphasizes on Islamic practice that compromise with culture, also compromise with spirit of union and nation unity. In the teachings of Islam Nusantara, it must be understood wholly what is meant by unbelievers who can be fought and also how the example of Prophet Muhammad (peace be upon him) in dealing with the unbelievers.

${ }^{20}$ Muhammed al-Dami, Feminizing the West: Neo-Islam's Concept of Renewal, War, and the State (New York: Thinkstock, 2014), 123. 
Islam Nusantara regards that every community exist in nation, whatever its faiths and religions, it must be protected and treated well, unless it indeed includes the criteria of those who are must be "fought". In the book Fiqh al-Jihad: Dirasah Muqaranah li Abkamibi wa Falsafatibi fi Dhau' Al-Qur'an wa as-Sunnah (2010), Yusuf al-Qaradhawi states that Islam divides unbeliever category into three groups. First, harbi unbelievers, are unbelievers who involved in the war. ${ }^{21}$ If there are 100 unbelievers men involved in the war with the Muslims, then those 100 men are the one who should be fought (killed) and the rests are not. But it must be remembered that the war will occur if the side who starts the war is the unbeliever, not the Muslim. However, before fighting against harbi unbelievers, there are some alternatives that need to be done such as peace negotiation, agreement, and so on. It means: fight or kill harbi unbelievers is the last resort. Hudaibiyah Agreement between Prophet and Quraisy unbeliever, for instance, was a form of Prophet's action to avoid war and bloodshed. The battle occured after Hudaibiyah Agreement was violated by the Quraisy unbelievers. This case shows that actually the Prophet wanted to uphold peace in the nation, which was in Mecca. The existences of unbelievers were actually still needed to be strived for living together in Prophet era. ${ }^{22}$

Second, musta'man unbelievers, who are temporarily entered the nation or Muslim territorial areas. This kind of unbelievers may not be harmed, disgraced, or killed. In fact, they should be protected. Rasulullah once said, "Those who harm musta'man unbelievers, they will not enter the heaven." Therefore, if in Indonesian nation, there are non-Muslim people for temporary, the teaching of Islam Nusantara sourced from Rasulullah emphasizes peace with them.

Third, dzimni unbelievers, who live in a nation (read: state) or Muslim's territory. The third category of unbelievers also

${ }^{21}$ Yusuf al-Qaradhawi, Fiqih Jihad, transl. Irfan Maulana Hakim, et al. (Bandung: Mizan, 2010), 298.

${ }^{22}$ Imam as-Suyuthi, Tarikh al-Khulafa: Ensiklopedia Pemimpin Umat Islam dari Abu Bakar hingga Mutawakkil, transl. Fachry (Jakarta: Hikmah, 2010), 77. 
cannot be fought or killed. In Indonesian context, there are lots of dzimni unbelievers, the teaching of Islam Nusantara also provides protection to them. Rasulullah also emphasized in some of hadith about obligation to protect dzimni unbelievers. Not only that, during his life, Rasulullah once had father in law from dzimni unbelievers, named Huyai bin Akhtab. ${ }^{23}$

He had daughter named Shafiyyah binti Huyai bin Akhtab r.a. who converted into Islam before married by the Prophet. However, his father, Huyai bin Akhtab, (father in law) was still belief in Jew until he died. Every night he joked and discussed with the Prophet without the slightest treatment from the Prophet. ${ }^{24}$

Related to the scene, Rasulullah once told:

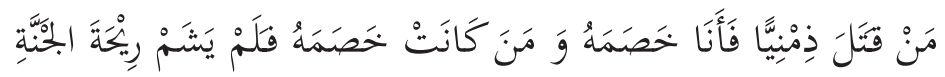

"Those who are fought against the dzimni's then I will be their enemy, and for those who against me then they will not breathe the heaven's scent." (H.R. Muslim)

Therefore, on whatever basis, acts of cruelty towards groups with different understanding are not actually part of Islamic teachings. In this case, Islam Nusantara stresses on concordance among humans and the entire groups in the nation. It means, whatever the religion, regardless its faith, whatever its madhhab, all of them can live in the land of Islam Nusantara.

Then, who is worth to be fought or killed? If it refers to the concept of the purpose of establishing Islamic law (maqashid asy-syari'ab) which maintains benefit in the field of five main things namely religion, soul, reason, descent, and property, then everything that threatens the five main points must be eradicated.

${ }^{23}$ Many people don not understand (not knowing that Prophet Muhammad once had fater in law (family) from non-Muslim circles (Jew). The nescience is cause by the lackness to study fully toward Prophet Muhammad. See, Maulana Muhammad Ali, Biografi Muhammad Rasulullah (Jakarta: Turos, 2015), 42.

${ }^{24} \mathrm{Ali}, 42$. 
On the contrary, everything supports the five principals should be maintained, guided, even obliged.

The anti-nationalism movements are conducted by groups who wanted to disrupt the benefit. They disrupt the soul (blindly killing), disrupt treasure, eliminate the offspring, threaten state stability, and worsen Islamic image in world. So then, the object that actually must be fought is radicalism.

To fight and eradicate these anti-nationalism movements is worth to call as Jihad action because it saves goodness. And, the struggle can be said as grand (akbar) jihad because anti-nationalism movements is now transformed into armed, hostile, tough, ruthless, and even slick militant group. The writer is totally agree if all of the nation unite fight against the anti-nationalism movements in order to preserve the goodness itself.

This case is in accordance with ushuliyyah principle that says, "Tasaharrufu al-imam 'ala ar-ra'iyyah manuthun bi al-maslabah." It means, every leader's policy (state) toward its citizen-whatever the forms-is in order to preserve the goodness.

The application of Islam Nusantara is essentially not just demand of academic culture or intellectual culture. It is more important than that, the application of Islam Nusantara is an inevitable necessity in our diversity. The desire to make peace with any teachings and religion is not to undermine religion itself, but to assign religious practice correctly according to the basis of religious message, that is compassion and peaceful.

Islam Nusantara as an inevitability is in order to embrace each other, look for common ground among many differences and disagreements, preserve diversity and acknowledge plurality as God's fitrah. The main point of all is tolerance and compassion among humans, whatever their religion and beliefs.

In a classic writing entitled The Conflict of Religions (1955), Philip H. Ashby advised us, "Faith conflict in religion cannot be 
resolved with war, guns, or even muscle and power, but it is resolved with dialogue." Phillip H. Ashby statement can be interpreted that faith conflict essentially is not lies in physical or political attitude, but it lies in the heart and mind which embodies the belief itself. To connect the contradiction is surely only by approaching the heart, in form of dialogue. And, all of that can be conducted by practicing Islam Nusantara.

Therefore, the writer hopes that every party will not have misperception toward the teaching of Islam Nusantara. This is because Islam Nusantara basically tries to preserve peace and opens for dialogue widely to muffle several endless conflicts. Now it is the time to implement Islam Nusantara, as Islam that teaches compassionate as what Rasulullah teaches to us, appreciates differences, and accepts culture and custom as parts of Islam, as long as it does not contradict the Islamic rules (syariah).

While it is conducted, violence will not appear in the name of Islam because Islam is always fused with plurality and diversity. So that, in world's view, Islamic world will be more prominent through the image of love and affection, not through acts of violence in the name of religious egoism. Only with these, we can prove to the world that Islam is not frightening and scary religion. And, the Muslim can enter and live in any country and any time.

\section{Conclusion}

Form the above long explanation, it can be concluded that Islam Nusantara ala NU (an-Nabdliyyah) is actually an embodiment of Islam as rabmatan lil 'alamin. That is, Islam can be said as religion that gives mercy and affection to the universe without exception if applied in every place and time. One way is by practicing Islam Nusantara as conducted by NU today. Therefore, Islam Nusantara is not a new religion, not a new teaching, not a new ideology, but Islam which originates from the Messenger of Allah and His companions. 
Badrun

In addition to accommodating the culture and traditions that are in accordance with the syariah, one of the urgencies of Islam Nusantara is to prevent the movement of religious radicalism that currently threatens nationalism. 


\section{REFERENCES}

al-A'zami, Muhammad Mustafa. Sejarah Teks Al-Qur'an: dari Wabyu sampai Kompilasi. Jakarta: Gema Insani Press, 2005.

Ali, Maulana Muhammad. Biografi Mubammad Rasulullah. Jakarta: Turos, 2015.

Aziz, Munawir (ed.). Islam Nusantara: dari Ushul Figh hingga Paham Kebangsaan. Bandung: Mizan, 2015.

al-Baghdadi, Abdurrohman and Adian Husaini. Hermeneutika dan Tafsir Al-Qur'an. Jakarta: Gema Insani, 2007.

Bagir, Muhammad. Fiqh Praktis. Bandung: Karisma, 2008.

Barnes SJ, Michael. Theology and the Dialogue of Religions. Cambridge University Press, 2002.

Baso, Ahmad. Islam Nusantara: Ijtihad Jenius dan Ijma’ Ulama Indonesia. Jakarta: Pustaka Afid, 2015.

al-Bukhari. Shahih al-Bukhari, "Janaiz Book", hadith number of 1.296, Hadith Program.

Bustam, Betty Mauli Rosa, dkk. Sejarah Sastra Arab dari Beragam Perspektif. Yogyakarta: Deepublish, 2015.

al-Dami, Muhammed. Feminizing the West: Neo-Islam's Concept of Renewal, War, and the State. New York: Thinkstock, 2014.

Gussenhoven, Carlos. The Phonology of Tone and Intonation. Cambridge: Cambridge University Press, 2004.

al-Indunisi, Ahmad Nahrawi Abdus Salam. Ensiklopedia Imam Syafi'i:

Biografi dan Mąhab Fiqh Terbesar Sepanjang Masa. Jakarta: Penerbit Himah, 2008.

Poerwadaminta, W.J.S. Kamus Umum Bahasa Indonesia. Jakarta: National Language Institute, 1972. 
Badrun

al-Qaradhawi, Yusuf. Fiqih Jihad, transl. Irfan Maulana Hakim, et al. Bandung: Mizan, 2010.

Romli, Muhamad Guntur. Islam Tanpa Diskriminasi: Mewujudkan Islam Rahmatan lil 'Alamin. Jakarta: Rehal Pustaka, 2013.

Safi, Louay. The Foundation of Knowledge: a Comparative Studying Islamic and Western Methods of Inquiry. Selangor: IIU and IIIT, 1996.

Setiawan, Zudi. Nasionalisme NU. Semarang: Aneka Ilmu, 2007.

Sholikhin, Muhammad. Ritual dan Tradisi Islam Jawa: Ritual-ritual dan Tradisi-tradisi Tentang Kehamilan, Kelabiran, Pernikahan, Kematian dalam Kehidupan Sehari-hari Masyarakat Islam Jawa. Yogyakarta: Narasi Press, 2010.

as-Suyuthi, Imam. Tarikh al-Khulafa: Ensiklopedia Pemimpin Umat Islam dari Abu Bakar hingga Mutawakkil, transl. Fachry. Jakarta: Hikmah, 2010.

Wahyudi, Yudian. Ushul Fiqh versus Hermeneutika: Membaca Islam dari Kanada dan Amerika. Yogyakarta: Pesantren Nawasea Press, 2007. 